\title{
KAJIAN YURIDIS TERHADAP PENETAPAN PELAKU PEKERJA SEKS KOMERSIL PROSTITUSI ONLINE SEBAGAI KORBAN TINDAK PIDANA PERDAGANGAN ORANG MENURUT HUKUM PIDANA INDONESIA (Studi Kasus di Wilayah Hukum Kepolisian Daerah Jambi)
}

\author{
Oleh : \\ Suzanalisa * \\ Abadi B Darmo * \\ Bunyamin Alamsyah *
}

\begin{abstract}
ABSTRAK
Prostitusi online merupakan kegiatan yang dilaksanakan telah terorganisir dimana terdiri pekerja seks komersil, mucikari atau germo (pimp) dan pelanggannya (client) ditambah dengan kemajuan teknologi melalui internet dimana media ini memang lebih aman jika dibandingkan dengan langsung menjajakan di pinggir jalan ataupun tempat lokalisasi. Dengan adanya media ini seseorang bisa lebih leluasa dalam bertransaksi, tidak harus saling bertemu langsung antara seorang pelaku prostitusi dengan orang yang ingin memakai jasanya. Sebagaimana kasus prostitusi online yang marak terjadi di Indonesia cara kerja dimulai Pekerja seks komersial akan mempromosikan dirinya melalui media sosial oleh mucikari selanjutnya pria hidung belang menemukan iklan pekerja seks tersebut kemudian berhubungan melalui media sosial dan di sambungkan dengan BBM atau Whatsapp setelah ada kata deal ingin bertemu. Prostitusi online yang terus berkembang membawa dampak negative terhadap Negara Indonesia antara lain merusak moral bangsa terutama genrasi penerus bangsa sebagai estafet penerus bangsa sehingga dapat mengancam kelangsunagn hidup bangsa dan Negara di masa mendatang, Lunturnya nilainilai Pancasila sebagai ideology bangsa yang dijadikan sebagai dasar pijakan berdirinya Negara Indonesia. Selanjutnya prostitusi online yang telah diungkap oleh Kepolisian Daerah Jambi semenjak tahun 2015 sampai dengan tahun 2018 diperoleh pekerja seks komersil berjumlah 42 orang dari 19 kasus. Pekerja seks komersil dalam prostitusi online adalah perempuan yang berumur antara 19 tahun - 30 tahun. Selanjutnya oleh Kepolisian Daerah Jambi ditetapkan sebagai korban tindak pidana perdagangan orang, untuk itulah menjadi ketertarikan penulis mengetahui dan menganalisis penetapan terhadap pekerja seks komersial dalam prostitusi online oleh Kepolisian Daerah Jambi sebagai korban perdagangan orang, dan selanjutnya penetapan yang telah dilakukan oleh Polda Jambi bukan merupakan penanggulangan dan pemberantasan prostitusi online.
\end{abstract}

Kata Kunci : Prostitusi Online, Korban, Tindak Pidana Perdagangan Orang

\footnotetext{
* PNS di Pemda Provinsi Jambi, Alumni Program Magister Ilmu Hukum Unbari.

* Pengajar Program Magister Ilmu Hukum Unbari.

* Pengajar Program Magister Ilmu Hukum Unbari.
} 


\section{A. Latar Belakang}

Prostitusi di Indonesia telah terjadi semenjak sebelum kemerdekaan yang menjamah dari kaum rakyat jelata sampai kaum elite. Prostitusi atau pelacuran dalam pandangan masyarakat Indonesia adalah salah satu perbuatan yang tercela dan melanggar norma kesusilaan, adat istiadat dan agama. Namun persepsi masyarakat yang memandang perbuatan ini adalah perbuatan tercela tidak menyurutkan praktik prostitusi di Indonesia. Masalah prostitusi adalah masalah yang rumit, banyak hal yang berhubungan disana oleh karena itu masalah ini sangat perlu perhatian khusus oleh masyarakat. Prostitusi, sebuah bisnis yang identik dengan dunia hitam ini merupakan salah satu bisnis yang mendatangkan uang dengan sangat cepat. Tidak perlu modal banyak, hanya beberapa tubuh yang secara profesional bersedia untuk dibisniskan. Karena itulah sampai kapanpun bisnis ini tidak akan menemui masa masa sulit. Prostitusi bukan hanya berdampak pada mereka yang melakukannya yaitu perlaku dan pemakai jasanya akan tetapi juga berimbas kepada masyarakat luas, prostitusi atau pelacuran bahkan membahayakan bagi kehidupan rumah tangga yang terjalin sampai bisa menimbulkan tindak pidana kejahatan dan lain sebagainya. Agama sebagai salah satu pedoman dalam hidup sama sekali tidak dihiraukan oleh mereka yang terlibat di dalam praktek prostitusi ini dan benar-benar merupakan perbuatan yang dilarang oleh agama. Pelacuran bukan hanya sebuah gejala individu akan tetapi sesudah menjadi gejala sosial dari penyimpangan seksualitas yang normal dan juga agama.

Dalam pengertian yang lain kata prostitusi berasal dari perkataan latin prostituere yang berarti menyerahkan diri dengan terang-terangan kepada perzinahan. Sedangkan secara etimologi berasal dari kata prostare artinya menjual, menjajakan. Jadi prostitusi adalah suatu transaksi antara si perempuan pelacur dan si pemakai jasa pelacur yang memberi sejumlah uang untuk interaksi seksual ${ }^{1}$. Aktivitas dan praktik prostitusi di Indonesia secara garis besar mewujud dalam dua bentuk yaitu prostitusi yang terdaftar dan terorganisir dan prsostitusi yang tidak terdaftar. Prostitusi yang terdaftar dalam menjalankan aktivitasnya. Pelakunya diawasi oleh bagian Vice Control dari kepolisian, yang dibantu dan bekerja sama dengan jawatan sosial dan jawatan kesehatan. Pada umumnya meeka dilokalisir dalam satu daerah tertentu. Penghuninya secara periodik harus memeriksakan diri pada dokter atau petugas kesehatan, dan

\footnotetext{
${ }^{1}$ S Simandjuntak, Patologi Sosial, Tarsito, Bandung, 2012, hal. 112
} 
mendapatkan suntikan serta pengobatan, sebagai tindakan dan keamanan umum. Sebagaimana Profesor W.A Bonger dalam tulisannya Maatschappelijke Oorzaken der Prostitutie menulis defenisi prostitusi ialah gejala kemasyarakatan di mana wanita menjual diri melakukan perbuatan-perbuatan seksual sebagai mata pencaharian. Menurut definisi ini Jelas dinyatakan adanya peristiwa penjualan diri sebagai profesi atau mata pencaharian sehari-hari dengan jalan melakukan relasi-relasi seksual. ${ }^{2}$

Dunia prostitusi menjanjikan pemenuhan sejuta impian. Prostitusi terhadap anak di bawah umur sangat menjanjikan permintaan pasar.Impian tersebut muncul dengan menjadikan wanita yang masih dibawahumur sebagai korban prostitusi. Terhadap perbuatan orang dewasa yangmelakukan prostitusi terhadap anak tersebut semacam penyakit masyarakatyang muncul dari berbagai tuntutan hidup. Praktek Prostitusi dikategorikan ke dalam "patologi sosial" atau penyakit masyarakat yangharus diupayakan penanggulanganya. ${ }^{3}$

Jika ditinjau pelaku Pekerja Seks Komersial (PSK), terdapat berbagai persoalan yang menyangkut tuntutan hidupnya sehingga tidak merasa bersalah dan enggan untuk dilindungi. Mereka seolah-olah senang dengan perbuatan tersebut. Salah satu faktor penyebabnya adalah tuntutan ekonomi dalam keluarga sehingga sekssebagai komoditi telah menumbuhkan suatu profesi yang memerlukantotalitas diri sebagai modal kerja. ${ }^{4}$

Kemajuan teknologi dan informasi telah memberikan banyak keuntungan disetiap lapisan masyarakat dan diberbagai bidang. Kemajuan teknologi dimaksud adalah adanya jaringan internet yang dapat diakses oleh siapapun dan dimanapun, namun kemajuan teknologi yang dapat dinikmati oleh siapapun ini telah menjadi peluang untuk dilakukan kejahatan yang menguntungkan pribadi maupun korporasi untuk proses lebih cepat dan biaya ringan. Salah satu kejahatan yang memanfaatkan fasilitas internet adalah pelacuran atau prostitusi. Prostitusi ini dikenal dengan istilah prostitusi online. Prostitusi online berbeda denga prostitusi yang tidak terdaftar, dimana dalam menjalankan aktivitasnya yaitu mereka yang melakukan prostitusi secara gelap-gelapan dan liar, baik secara perorangan maupun dalam kelompok. Perbuatannya tidak terorganisir, tempatnya pun tidak tertentu. Bisa disembarang tempat, baik mencari mangsa sendiri maupun melalui calo-calo dan panggilan. Mereka tidak mencatatkan diri kepada yang berwajib. Sehingga kesehatannya sangat

\footnotetext{
${ }^{2}$ Kartini Kartono, Patologi Sosial, Jilid 1, Rajawali Press, Jakarta, 2013, Hal.214

${ }^{3}$ Kartini Kartono, Pathologi Sosial I, CV. Rajawali, Jakarta, 2008, hal. 13

${ }^{4}$ Ashadi Siregar, Menyusuri Remang-Remang Jakarta, Sinar Harapan, Jakarta, 1997, hal. 5
} 
diragukan, karena belum tentu mereka itu mau memeriksakan kesehatannya kepada dokter.

Selanjutnya bila dibandingkan dengan prostitusi online, kegiatan yang dilaksanakan telah terorganisir dimana terdiri pekerja seks komersil, mucikari atau germo (pimp) dan pelanggannya (client) ditambah dengan kemajuan teknologi melalui internet dimana media ini memang lebih aman jika dibandingkan dengan langsung menjajakan di pinggir jalan ataupun tempat lokalisasi. Dengan adanya media ini seseorang bisa lebih leluasa dalam bertransaksi, tidak harus saling bertemu langsung antara seorang pelaku prostitusi dengan orang yang ingin memakai jasanya. Sebagaimana kasus prostitusi online yang marak terjadi di Indonesia cara kerja dimulai Pekerja seks komersial akan mempromosikan dirinya melalui media sosial oleh mucikari selanjutnya pria hidung belang menemukan iklan pekerja seks tersebut kemudian berhubungan melalui media sosial dan di sambungkan dengan BBM atau Whatsapp setelah ada kata deal ingin bertemu. Biasanya jika proses sebelum deal pria hidung belang di harapkan memberi downpayment terlebih dahulu untuk meyakinkan pekerja seks. Dalam iklan yang di promosikan di media sosial para pekerja seks sudah menentukan secara lengkap layanan yang akan diterima oleh para pria hidung belang tersebut. Setelah berhubungan melalui BBM atau Whatsapp, maka akan menentukan dimana tempat pelaksanaannya. Setelah selesai biasanya lelaki hidung belang akan langsung meminta nomor handphone untuk mempermudah memanggilnya kembali suatu saat jika membutuhkan. Cara kerja yang telah diuraikan Kementian Komunikasi dan Informasi Republik Indonesia sampai tahun 2016 telah memblokir situs sebanyak 900.000,- yang memiliki muatan porno dan prostitusi berdasarkan Peraturan Menkominfo No.19/2014 tentang Penanganan Situs Internet Bermuatan Negatif.

Prostitusi online yang terus berkembang membawa dampak negative terhadap Negara Indonesia antara lain merusak moral bangsa terutama genrasi penerus bangsa sebagai estafet penerus bangsa sehingga dapat mengancam kelangsunagn hidup bangsa dan Negara di masa mendatang, Lunturnya nilai-nilai Pancasila sebagai ideology bangsa yang dijadikan sebagai dasar pijakan berdirinya Negara Indonesia. Nilai-nilai agama, moral, dan social akan tersisihkan, dan hanya akan tertinggal kebudayaan liberalisme, prostitusi dapat dimanfaatkan oleh pihak luar untuk merusak ketahanan nasioanal, menjatuhkan jati diri bangsa Indonesia yang tersohor dengan luhur budinya dan menjunjung tinggi nilai budaya ketimuran dan 
agamanya dan prostitusi online dapat menimbulkan dan menyebarluaskan penyakit kelamin dan kulit. Prostitusi online merupakan tindak pidana dan untuk itu dibutuhkan kehadiran hukum pidana, maka diperlukan kehadiran hukum pidana, pada dasarnya, kehadiran hukum pidana di tengah masyarakat dimaksudkan untuk memberikan rasa aman kepada individu maupun kelompok dalam masyarakat dalam melaksanakan aktifitas kesehariannya.

Rasa aman yang dimaksudkan dalam hal ini adalah perasaan tenang, tanpa ada kekhawatiran akan ancaman ataupun perbuatan yang dapat merugikan antar individu dalam masyarakat. Kerugian sebagaimana dimaksud tidak hanya terkait kerugian di tengah masyarakat dimaksudkan untuk memberikan rasa aman kepada individu maupun kelompok dalam masyarakat dalam melaksanakan aktifitas kesehariannya. Rasa aman yang dimaksudkan dalam hal ini adalah perasaan tenang, tanpa ada kekhawatiran akan ancaman ataupun perbuatan yang dapat merugikan antar individu dalam masyarakat. Kerugian sebagaimana dimaksud tidak hanya terkait kerugian sebagaimana yang kita pahami dalam istilah keperdataan, namun juga mencakup kerugian terhadap jiwa dan raga. Raga dalam hal ini mencakup tubuh yang juga terkait dengan nyawa seseorang, jiwa dalam hal ini mencakup perasaan atau keadaan psikis.

Prostitusi online yang telah diungkap oleh Kepolisian Daerah Jambi semenjak tahun 2015 sampai dengan tahun 2018 diperoleh pekerja seks komersil berjumlah 42 orang dari 19 kasus. Pekerja seks komersil dalam prostitusi online adalah perempuan yang berumur antara 19 tahun - 30 tahun. Selanjutnya oleh Kepolisian Daerah Jambi ditetapkan sebagai korban tindak pidana perdagangan orang, untuk itulah menjadi ketertarikan penulis mengapa pekerja seks komersial dalam prostitusi online ini ditetapkan hanya sebagai korban?, dan apakah hal ini penetapan yang telah dilakukan oleh Polda Jambi merupakan penanggulangan dan pemberantasan prostitusi online?

\section{B. PERUMUSAN MASALAH}

Berdasarkan uraian yang telah dikemukakan, maka perumusan masalah dalam penelitian ini adalah

1. Bagaimanakah pengaturan penetapan pelaku pekerja seks komersil prostitusi online sebagai korban tindak pidana perdagangan orang menurut hukum pidana Indonesia? 
2. Apakah yang menjadi dasar penetapan Kepolisian Daerah Jambi terhadap pelaku pekerja seks komersil prostitusi online sebagai korban tindak pidana perdagangan orang ?

3. Bagaimakah penanggulangan dan pemberantasan prostitusi online di wilayah hukum Kepolisian Daerah Jambi dapat tercapai bila pelaku pekerja komersil prostitusi online hanya ditetapkan sebagai korban?

\section{METODE PENELITIAN}

1. Tipe Penelitian

Berdasarkan perumusan masalah dan tujuan penelitian, maka pendekatan yang dilakukan dalam penelitian ini adalah "Yuridis Empiris". Yakni mempelajari peraturan perundang-undangan yang ada kemudian dihubungkan dengan pelaksanaannya dalam penetapan terhadap pekerja seks komersil prostitusi online sebagai korban tindak pidana perdagangan orang.

2. Spesifikasi Penelitian

Spesifikasi yang digunakan dalam penelitian ini adalah spesifikasi penelitian yang bersifat deskriptif analitis, yaitu memberikan gambaran dan uraian pertanggungjawaban pidana bagi pelaku pekerja seks komersil prostitusi online di wilayah hukum Kepolisian Daerah Jambi.

3. Pengolahan dan Analisis Bahan Hukum

Setelah bahan-bahan hukum tersebut terkumpul, maka dilakukan analisis terhadap pengertian-pengertian hukum dan norma-norma hukum, dengan cara melihat isi dari berbagai macam peraturan perundang-undangan yang berhubungan dengan masalah tindak pidana prostitusi online wilayah hukum Kepolisian Daerah Jambi.

Dari semua data yang diperoleh baik data primer maupun data sekunder yang telah dikumpulkan, diseleksi dan data tersebut diklasifikasikan. Setelah diklasifikasikan kemudian dilakukan analisis secara kualitatif kemudian hasilnya diu $\quad$ I secara deskriptif.Data yang terkumpul diseleksi dan diklasifikasi sesuaı dengan karakteristiknya, lalu dilakukan analisis secara kualitatif. Interprestasi hasil penelitian disajikan secara deskriptif.

\section{Pengaturan Penetapan Pelaku Pekerja Seks Komersil Prostitusi Online Sebagai Korban Tindak Pidana Perdagangan Orang Menurut Hukum Pidana Indonesia}


Semakin maju teknologi informasi melalui internet telah menimbulkan peluang bagi para pekerja seks, mucikari maupun para pengguna (client) untuk memanfaatkan dan lebih aman untuk memperlancar aksinya, lebih aman dari razia petugas, terutama bagi pekerja seks yang tidak perlu menjajakan dipingir-pinggir jalan raya. Hal inilah tumbuh berbagai macam situs-situs prostitusi online, adanya media ini seseorang bisa lebih leluasa dalam bertransaksi, tidak harus saling bertemu langsung antara seorang pelaku prostitusi dengan orang yang ingin memakai jasanya. Sehingga prostitusi online menjadi gejala sosial, sistemnya terletak pada faktor kondisional khususnya sifat biologis pria dan wanita serta hubungan dengan berbagai aspek kehidupan manusia yang kompleks, sehingga mustahil untuk dapat dihilangkan sama sekali. Maka berbagai usaha dan tindakan menghadapi masalah ini targetnya pun tidak sampai dengan pelenyapan sama sekali yang pasti tidak mungkin, melainkan pengarahan untuk membendung meluasnya dan mencegah berbagai akibatnya. $^{5}$

Sebagaimana diatur di dalam UUD 1945 sebagai dasar Negara Indonesia pada Pasal 28 J Ayat (1) : Setiap orang wajib menghormati hak asasi manusia orang lain dalam tertib kehidupan bermasyarakat, berbangsa, dan bernegara dan Pasal 28 J ayat (2) UUD 1945 bahwa dalam menjalankan hak dan kebebasannya, setiap orang wajib tunduk kepada pembatasan yang ditetapkan dengan undang-undang dengan maksud semata-mata untuk menjamin pengakuan serta penghormatan atas hak kebebasan orang lain dan untuk memenuhi tuntutan yang adil sesuai dengan pertimbangan moral, nilai-nilai agama, keamanan.dihubungkan dengan prostitusi online yang telah menimbulkan dampak negative berupa merusak moral bangsa terutama genrasi penerus bangsa sebagai estafet penerus bangsa sehingga dapat mengancam kelangsunagn hidup bangsa dan Negara di masa mendatang, Lunturnya nilai-nilai Pancasila sebagai ideology bangsa yang dijadikan sebagai dasar pijakan berdirinya Negara Indonesia. Nilai-nilai agama, moral, dan social akan tersisihkan, dan hanya akan tertinggal kebudayaan liberalisme, prostitusi dapat dimanfaatkan oleh pihak luar untuk merusak ketahanan nasioanal, menjatuhkan jati diri bangsa Indonesia yang tersohor dengan luhur budinya dan menjunjung tinggi nilai budaya ketimuran dan agamanya dan prostitusi online dapat menimbulkan dan menyebarluaskan penyakit kelamin dan kulit maka perlunya pengaturan dari Pemerintah Indonesia

\footnotetext{
${ }^{5}$ Yesmil Anwar dan Andang. Kriminologi. Refleksi Aditama: Bandung 2010. Hal. 361.
} 
Berdasarkan pertimbangan ini, maka Pemerintah Indonesia telah memiliki peraturan perundang undangan dalam penegakan hukum terhadap prostitusi online yang marak terjadi di Indonesia yaitu Kitab Undang Undang Hukum Pidana, Undang Undang Nomor 39 Tahun 1999 tentang Hak Asasi Manusia, Undang-undang Republik Indonesia Nomor 21 Tahun 2007 Tentang Pemberantasan Tindak Pidana Perdagangan Orang, UndangUndang RI No.44 Tahun 2008 Tentang Pornografi, Undang-Undang RI No.19 Tahun 2016 Tentang Perubahan Undang Undang Nomor 14 Tahun 2008 tentang Informasi dan Transaksi Elektronik.

Di dalam KUHP, terdapat 3 (tiga) Pasal yang berhubungan dengan perbuatan prostitusi yang memberikan penjelasan lebih jelas sanksi bagi pelaku tindak pidana prostitusi yang yang selengkapnya menyatakan bahwa :

Pasal 296 yang menyatakan bahwa "Barangsiapa dengan sengaja menghubungkan atau memudahkan perbuatan cabul oleh orang lain, dan menjadikannya sebagai pencarian atau kebiasaaan, diancam dengan pidana penjara paling lama satu tahun empat bulan atau denda paling banyak seribu rupiah",

Pasal 297 KUHP menyatakan bahwa "Perdagangan wanita dan perdagangan anak laki-laki yang belum cukup umur, diancam dengan pidana penjara paling lama enam tahun

dan Pasal 506 yang menyatakan bahwa " Barangsiapa menarik keuntungan dari perbuatan cabul seorang wanita dan menjadikan sebagai pencarian, diancam dengan kurungan paling lama satu tahun”.

Penelusuran selanjutnya Undang Undang Nomor 39 Tahun 1999 tentang Hak Asasi Manusia yang menggariskan bahwa :

pasal 23 yang menyatakan bahwa:

(1) Setiap orang bebas untuk memilih dan mempunyai keyakinan politiknya.

(2) Setiap orang bebas untuk mempunyai, mengeluarkan dan menyebarluaskan pendapat sesuai hati nuraninya, secara lisan dan atau tulisan melalui media cetak maupun elektronik dengan memperhatikan nilai-nilai agama, kesusilaan, ketertiban, kepentingan umum, dan keutuhan negara.

Pasal 73 yang menyatakan bahwa:

"Hak dan kebebasan yang diatur dalam Undang-undang ini hanya dapat dibatasi oleh dan berdasarkan undang-undang, semata-mata untuk menjamin pengakuan dan 
penghormatan terhadap hak asasi manusia serta kebebasan dasar orang lain, kesusilaan, ketertiban umum, dan kepentingan bangsa

Tindak pidana Prostitusi online merupakan tindakan perdagangan orang, maka hal ini melanggar Undang-undang Republik Indonesia Nomor 21 Tahun 2007 Tentang Pemberantasan Tindak Pidana Perdagangan Orang. Perdagangan orang dimaksud dalam tulisan ini tindakan perekrutan, pengangkutan, penampungan, pengiriman, pemindahan, atau penerimaan seseorang dengan ancaman kekerasan, penggunaan kekerasan, penculikan, penyekapan, pemalsuan, penipuan, penyalahgunaan kekuasaan atau posisi rentan, penjeratan utang atau memberi bayaran atau manfaat, sehingga memperoleh persetujuan dari orang lain tersebut, baik yang dilakukan dalam Negara maupun antar Negara, untuk tujuan eksploitasi atau mengakibatkan tereksploitasi. Ketentuan sanksinya beragam, yaitu penjara berkisar minimum tiga tahun hingga seumur hidup dan denda berkisar minimum Rp. 120.000.000,- (seratus dua puluh juta rupiah) hingga Rp. 5.000.000.000,- (lima milyar rupiah), tergantung pada kategori tindakannya sebagaimana diatur di dalam Pasal 2 Undang-undang Republik Indonesia Nomor 21 Tahun 2007 Tentang Pemberantasan Tindak Pidana Perdagangan Orang menyatakan sebagai berikut :

Pasal 2

(1) Setiap orang yang melakukan perekrutan, pengangkutan, penampungan, pengiriman, pemindahan, atau penerimaan seseorang dengan ancaman kekerasan, penggunaan kekerasan, penculikan, penyekapan, pemalsuan, penipuan, penyalahgunaan kekuasaan atau posisi rentan, penjeratan utang atau memberi bayaran atau manfaat walaupun memperoleh persetujuan dari orang yang memegang kendali atas orang lain, untuk tujuan mengeksploitasi orang tersebut di wilayah negara Republik Indonesia, dipidana dengan pidana penjara paling singkat 3 (tiga) tahun dan paling lama 15 (lima belas) tahun dan pidana denda paling sedikit Rp120.000.000,00 (seratus dua puluh juta rupiah) dan paling banyak Rp600.000.000,00 (enam ratus juta rupiah)”.

(2) Jika perbuatan sebagaimana dimaksud pada ayat (1) mengakibatkan orang tereksploitasi, maka pelaku dipidana dengan pidana yang sama sebagaimana dimaksud pada ayat (1)

Unsur-unsur pidana yang dipenuhi didalam Undang Undang ini adalah setiap orang, yang melakukan: perekrutan, pengangkutan, penampungan, pengiriman, pemindahan, atau penerimaan seseorang dengan ancaman kekerasan, penggunaan kekerasan, penculikan, 
penyekapan, pemalsuan, penipuan, penyalahgunaan kekuasaan atau posisi rentan, penjeratan utang atau memberi bayaran atau manfaat, sehingga memperoleh persetujuan dari orang lain tersebut. Selanjutnya perbuatan tersebut di atas harus mempunyai tujuan untuk mengeksploitasi (perhatikan ketentuan pasal 2 ayat1) atau mengakibatkan tereksploitasi (perhatikan ketentuan pasal 2 ayat 2).

Konten-konten yang ditawarkan mengenai criteria, cirri-ciri, foto-foto pekerja seks dan jasa prostitusi di dalam situs-situs prostitusi online juga telah melanggar UndangUndang RI No.44 Tahun 2008 Tentang Pornografi lebih lengkapnya terdapat pada Pasal 4, 7 sebagai berikut :

Pasal 4

(1) Setiap orang dilarang memproduksi, membuat, memperbanyak, menggandakan, menyebarluaskan, menyiarkan, mengimpor, mengekspor, menawarkan, memperjualbelikan, menyewakan, atau menyediakan pornografi yang secara eksplisit memuat:

a. persenggamaan, termasuk persenggamaan yang menyimpang;

b. kekerasan seksual;

c. masturbasi atau onani;

d. ketelanjangan atau tampilan yang mengesankan ketelanjangan;

e. alat kelamin; atau

f. pornografi anak.

(2) Setiap orang dilarang menyediakan jasa pornografi yang:

a. menyajikan secara eksplisit ketelanjangan atau tampilan yang mengesankan ketelanjangan;

b. menyajikan secara eksplisit alat kelamin;

c. mengeksploitasi atau memamerkan aktivitas seksual; atau

d. menawarkan atau mengiklankan, baik langsung maupun tidak langsung layanan seksual.

Pasal 7

Setiap orang dilarang mendanai atau memfasilitasi perbuatan sebagaimana dimaksud dalam Pasal 4.

Pasal 29

Setiap orang yang memproduksi, membuat, memperbanyak, menggandakan, menyebarluaskan, menyiarkan, mengimpor, mengekspor, menawarkan, 
memperjualbelikan, menyewakan, atau menyediakan pornografi sebagaimana dimaksud dalam Pasal 4 ayat (1) dipidana dengan pidana penjara paling singkat 6 (enam) bulan dan paling lama 12 (dua belas) tahun dan/atau pidana denda paling sedikit Rp. 250.000.000,00 (dua ratus lima puluh juta rupiah) dan paling banyak Rp. 6.000.000.000,00 (enam miliar rupiah).

Pasal 30

Setiap orang yang menyediakan jasa pornografi sebagaimana dimaksud dalam Pasal 4 ayat (2) dipidana dengan pidana penjara paling singkat 6 (enam) bulan dan paling lama 6 (enam) tahun dan/atau pidana denda paling sedikit Rp. 250.000.000,00 (dua ratus lima puluh juta rupiah) dan paling banyak Rp. 3.000.000.000,00 (tiga miliar rupiah).

Tindak pidana prostitusi online selanjutnya melanggar Undang Undang RI No.19 Tahun 2016 Tentang Perubahan Undang Undang Nomor 14 Tahun 2008 tentang Informasi dan Transaksi Elektronik. Undang Undang RI No.19 Tahun 2016 merupakan perubahan Undang Undang Nomor 14 Tahun 2008 tentang Informasi dan Transaksi Elektronik dalam rangka untuk menjamin pengakuan serta penghormatan atas hak dan kebebasan orang lain dan untuk memenuhi tuntutan yang adil sesuai dengan pertimbangan keamanan dan ketertiban umum dalam suatu masyarakat yang demokratis perlu dilakukan perubahan terhadap Undang-Undang Nomor 11 Tahun 2008 tentang Informasi dan Transaksi Elektronik agar terwujud keadilan, ketertiban umum, dan kepastian hukum. Sebagaimana diatur didalam Pasal 27 ayat (1) UU Nomor 19 Tahun 2016 tentang Perubahan UU Nomor 11 Tahun 2008 , berbunyi. Setiap Orang dengan sengaja dan tanpa hak mendistribusikan dan/atau mentransmisikan dan/atau membuat dapat diaksesnya Informasi Elektronik dan/atau Dokumen Elektronik yang memiliki muatan yang melanggar kesusilaan dengan ancaman pidana diatur didalam Pasal 45 ayat (1) menyatakan bahwa Setiap Orang yang dengan sengaja dan tanpa hak mendistribusikan dan/atau mentransmisikan dan/atau membuat dapat diaksesnya Informasi Elektronik dan/atau Dokumen Elektronik yang memiliki muatan yang melanggar kesusilaan sebagaimana dimaksud dalam Pasal 27 ayat (1) dipidana dengan pidana penjara paling lama 6 (enam) tahun dan/atau denda paling banyak Rp1.000.000.000,00 (satu miliar rupiah).

\section{E. Dasar penetapan Kepolisian Daerah Jambi terhadap pelaku pekerja seks komersil prostitusi online sebagai korban tindak pidana perdagangan orang}


Prostitusi online yang telah diungkap oleh Kepolisian Daerah Jambi semenjak tahun 2015 sampai dengan tahun 2018 diperoleh pekerja seks komersil berjumlah 42 orang dari 19 kasus. Pekerja seks komersil dalam prostitusi online adalah perempuan yang berumur antara 19 tahun - 30 tahun. Selanjutnya oleh Kepolisian Daerah Jambi ditetapkan sebagai korban tindak pidana perdagangan orang. Hal ini didasarkan kepada Kepolisian merupakan salah satu sub system penegakan hokum dalam tindak pidana perdagangan orang.

Untuk itu tim peneliti pertama - tama mengemukakan factor-faktor penyebab berkembangnya prostitusi online di wilayah hokum kepolisian Daerah Jambi. Berdasarkan hasil wawancara dengan Iin Asi Noprini, S.Psi di wilayah Provinsi Jambi diperoleh bahwa factor-faktor penyebab terjadinya prostitusi online dipengaruhi factor-faktor sebagai berikut :

1. Ditutupnya lokalisasi prostitusi di daerah-daerah

Adanya kebijakan yang dikeluarkan oleh pemerintah daerah terkait dengan lokalisasi prostitusi di beberapa lokasi pada Provinsi Jambi walaupun pemerintah daerah ditempat lokalisasi telah melakukan kebijakan pemberian pesangon dan lapangan kerja untuk para pekerja seks dan mucikari namun hal ini tidak menghentikan prostitusi, namun pekerja seks komersial memanfaatkan media sosial sebagai sarana transaksi prostitusi dengan aman dan mudah dalam mendapatkan client.

2. Bagi Pekerja Seks

a. Harga jual lebih mahal

- Tawaran yang diberikan di situs prostitusi online lebih mahal dibandingkan di jalanan maupun di lokalisasi dan tidak membutuhkan waktu yang lama dalam mendapatkan persetujuan hal ini memberikan keuntungan kepada pekerja seks

b. Lebih aman

- $\quad$ Melalui media prostitusi online keuntungan lainnya yang didapatkan adalah keamanan kepada pekerja seks, karena telah jelas dimana tempat pertemuan, dan perjanjian - perjanjian segala sesuatu telah dilaksanakan oleh mucikari dan pelanggan lebih mematuhinya berdasarkan hasil penelitian bahwa rata-rata pelanggan yang diperoleh dari prostitusi online adalah orang-orang yang tergolong pendidikan dan keuangan lebih baik dari prostitusi di jalanan atau lokalisasi

c. Tidak beresiko berurusan dengan hukum 
- $\quad$ Prostitusi di jalanan lebih beresiko dari razia-razia oleh penegak hukum baik di hotel-hotel sehingga baik pekerja seks maupun pelanggan merasa tidak nyaman berbanding terbalik apabila melalui prostusi online segala sesuatu telah diatur dengan baik dan memberikan kenyamanan kepada pekerja seks

3. mucikari atau germo (pimp)

a. Lebih cepat proses transaksi

Melalui media social prostitusi yang ditawarkan lebih cepat dan tidak memerlukan waktu yang lama dalam menemukan kata sepakat dan pembayaran yang cepat pula sebagaimana cara kerja dimulai Pekerja seks komersial akan mempromosikan dirinya melalui media sosial oleh mucikari selanjutnya pria hidung belang menemukan iklan pekerja seks tersebut kemudian berhubungan melalui media sosial dan di sambusngkan dengan BBM atau Whatsapp setelah ada kata deal ingin bertemu. Biasanya jika proses sebelum deal pria hidung belang di harapkan memberi downpayment terlebih dahulu untuk meyakinkan pekerja seks. Dalam iklan yang di promosikan di media sosial para pekerja seks sudah menentukan secara lengkap layanan yang akan diterima oleh para pria hidung belang tersebut. Setelah berhubungan melalui BBM atau Whatsapp, maka akan menentukan dimana tempat pelaksanaannya. Setelah selesai biasanya lelaki hidung belang akan langsung meminta nomor handphone untuk mempermudah memanggilnya kembali suatu saat jika membutuhkan.

b. lebih banyak untung dalam hal pembagian hasil harga jual atau penawaran yang diberikan melalui prostitusi online lebih mahal dibandingkan prostitusi jalanan / di lokalisasi, sehingga hal ini akan mempengaruhi kepada keuntungan yang diperoleh oleh mucikari

c. lebih mudah diawasi keselamatan pekerja seksnya sebagaimana telah diuraikan diatas, bahwa melalui cara kerja prostitusi online langsung ditentukan tempat pertemuan antara pekerja seks dengan client yang telah diatur oleh mucikari, hal ini memberikan keuntungan lainnya bahwa mucikari akan lebih mudah mengawasi keselamatan pekerja seks dari tindakan-tindakan client yang melanggar perjanjian

4. pelanggan (client).

a. Kehormatan (nama baik) lebih terjaga 
- Prostitusi online sangat memberikan keuntungan kepada client yang memakai jasa pekerja seks dibandingkan client yang harus datang ke lokalisasi pelacuran ataupun mencari pekerja seks di jalanan dikarenakan dapat menjaga nama baik dan keututuhan rumah tangga bagi client sehingga melalui prostitusi online tidak akan diketahui bahwa pribadi-pribadi client yang suka memakai jasa pekerja seks

b. lebih banyak pilihan dengan tarif yang diinginkan

- $\quad$ melalui prostitusi online memberikan keuntungan juga kepada client bahwa telah tersedia tawaran-tawaran jasa dari pekerja seks dan criteria, cirri-ciri yang memenuhi keinginan client yang dapat dilihat melalui situs-situs yang telah tersedia sehingga melalui prostitusi online sebagai sarana pemenuhan kebutuhan client $^{6}$ selanjutnya ditemukan factor yang menyebabkan prostitusi onlime terus berkembang yang bisa mudah diakses oleh pengguna di Provinsi Jambi berasal dari factor internal dan ekternal pekerja seks itu sendiri sebagai berikut :

1. Faktor Moral atau Akhlak, terdiri dari

a. rendahnya faktor moral, ketakwaan seseorang terhadap ajaran agamanya.

b. pemahaman pentingnya Pendidikan yang ada didalam keluarga sehingga mempengaruhi pola pikir

c. mudahnya akses pornografi dikarenakan kurang pengawasan dari keluarga secara bebas.

\section{Faktor Ekonomi}

Tingkat kehidupan yang susah dan miskin didukung oleh keinginan untuk hidup mewah tanpa harus kerja keras, merasa tidak memiliki kemampuan, keterampilan khusus, tingkat pendidikan rendah sehingga memiliki pemikiran segala hal ditempuh sehingga pekerja seks akan ditempuh.

3. Faktor Sosiologis

a. Ajakan dari teman-teman sedaerahnya yang sudah lebih dahulu terjun ke dunia prostitusi

b. Pengalaman dan pendidikan mereka sangat minim, akhirnya mereka dengan mudah terbujuk dan terkena tipuan dari pria. Terutama dengan menjanjikan pekerjaan terhormat dengan gaji tinggi yang akhirnya dijebloskan ke tempat-tempat prostitusi.

\section{Faktor Psikologis}

\footnotetext{
${ }^{6}$ Iin Asi Noprini, S.Psi, Kepala UPTD P2TP2A Provinsi Jambi, Wawancara Tanggal 10 Juli 2019
} 
Pengalaman-pengalaman hidup semenjak kecil maupun yang ditemui setelah dewasa baik dari keluarga maupun lingkungan seperti kekerasan seksual, perceraian orang tua, kegagalan dalam perkawinan, dimadu, menimbulkan luka jiwa sehingga prostitusi sebagai pelarian untuk menikmati kesenangan dan obat terhadap luka jiwa yang dialaminya.

\section{Faktor kemalasan}

Faktor kemalasan biasanya diakibatkan oleh psikis dan mental yang rendah, tidak memiliki norma agama dan susila menghadapi persaingan hidup. Hanya dengan modal fisik, kecantikan sehingga dengan mudah mengumpulkan uang.

6. Faktor Biologis

Adanya nafsu seks yang abnormal, tidak terintegrasi dalam kepribadian yang tidak merasa puas mengadakan relasi seks dengan satu istri/suami.

\section{Faktor Pendukung}

Kemajuan teknologi dan informasi yaitu internet dan handphone yang telah bermigrasi sebagai android sehingga memudahkan akses internet tanpa harus memakai computer membuat seseorang dengan mudah dapat bertransaksi prostitusi ${ }^{7}$.

Faktor penyebab dan pendukung yang terjadinya marak prostitusi online di Provinsi Jambi ini menjadi bahan pertimbangan oleh Kepolisian Daerah Provinsi Jambi menetapkan pelaku pekerja komersil prostitusi Online sebagai korban, hal ini berdasarkan data yang diperoleh bahwa para pekerja seks prostitusi online hasil penyidikan dan penangkapan di lokasi merupakan perempuan-perempuan berumur 15-21 tahun yang dipersiapkan oleh Mucikari kepada client berdasarkan transaksi-transaksi yang diperjualbelikan oleh Mucikari melalui media social.

Temuan yang diperoleh di dalam penelitian ini senada dengan Kasus trafficking merupakan kasus yang sulit diproses dan diselesaikan dikarenakan, Pertama, sulit pembuktiannya dan terdapat beberapa daerah baik di dalam negeri maupun sampai di luar negeri sebagai tempat kejadian Perkara (TKP). Kedua, sebagian besar korban enggan melapor dan memilih berdiam diri dengan penderitaan lahir batinnya. Keengganan untuk membuka diri tersebut erat hubungannya dengan masih kuatnya anggapan bahwa melaporkan kasus trafficking yang menimpa dirinya sama dengan menguak aib pribadi maupun keluarga. Ketiga, sebagian masyarakat beranggapan bahwa trafficking terjadi

\footnotetext{
${ }^{7}$ Nuraini Silalahi, Satgas Perlindungan Perempuan dan Pemberdayaan Anak Provinsi Jambi, Wawancara Tanggal 5 Agustus 2019
} 
akibat kesalahan korban sendiri. Umumnya, bila korban menceritakan nasib sial yang menimpa dirinya kepada seseorang, mereka lebih banyak yang bersikap menyalahkan, dari pada memberikan bantuan atau dukungan moral. Akibatnya korban mengalami pelecehan dan menjadi korban untuk kedua kalinya, Harkristuti Harkrisnowo ${ }^{8}$ mengemukakan ada beberapa kendala yang berasal dari korban sebagal berikut:

1. Korban mengetahui bahwa dirinya telah menjadi korban kejahatan tidak bersedia melapor karena menganggap polisi tidak efisien atau tidak akan memperdulikan laporannya dan menganggap peristiwa tersebut, sebagai urusan pribadi dan akan menyelesaikannya di luar (ekstra yudisiil) atau merasa malu.

2. Korban tidak mengetahui bahwa dirinya menjadi korban dari suatu perbuatan pidana. Hal ini dapat terjadi dalam kejahatan-kejahatan penipuan atau penggelapan yang modus operandinya dilakukan dengan cara yang halus, sehingga korban tidak merasa telah tertipu.

3. Korban yang sifatnya abstrak (abstract victim). Jenis korban ini sering terjadi pada penipuan konsumen. Oleh karena itu sulit untuk menentukan siapa sebenarnya yang menjadi korban.

4. Korban sendiri sekaligus sebagai pelaku kejahatan. Untuk jenis kejahatan ini sering disebut sebagai kejahatan tanpa korban (crime without victim) seperti kejahatan narkotika, abortus dan pejudian.

5. Secara resmi tidak terjadi korban karena kewenangan (diskresi) kepolisian untuk menentukan peristiwa apa dan mana yang merupakan kejahatan. Diskresi kepolisian ini sangat berkaitan dengan kebijakan dan penegakan hukum. Dengan demikian nampak bahwa sangat mungkin korban dari kejahatan human trafficking merasa enggan, malas serta malu untuk melaporkan bahwa dirinya telah menjadi korban dari suatu kejahatan.

\section{F. Penanggulangan dan pemberantasan prostitusi online di wilayah hukum} Kepolisian Daerah Jambi dapat tercapai bila pelaku pekerja komersil prostitusi online hanya ditetapkan sebagai korban

Adanya penetapan pekerja seks komersial prostitusi onlie ditetapkan hanya sebagai korban, hal ini berdasarkan pertimbangan - pertimbangan yang dilakukan oleh Penyidik Kepolisian Daerah Jambi yang memiliki hak diskresi sebagaimana menurut AKP Yanepi

\footnotetext{
${ }^{8}$ Harkristuti Harkrisnowo, Laporan Perdagangan Manusia Di Indonesia, Sentra HAM UI, 23 Februari 2003, Hal. 108
} 
mengutip pendapat Soerjono Soekanto bahwa dalam proses penegakan hukum terhadap kasus prositusi online di wilayah hukum Kepolisian Daerah Jambi, didasarkan menyerasikan hubungan nilai-nilai yang dijabarkan di dalam kaidah-kaidah yang mantap dan mengejawantah dan sikap tindak sebagai rangkuman penjabaran nilai tahap akhir, untuk menciptakan, memelihara dan mempertahankan kedamaian pergaulan hidup sehingga dalam proses penegakan hukum memghasilkan keputusan yang tidak secara ketat diatur oleh kaidah hukum, akan tetapi mempunyai unsur penilaian pribadi dan pada hakekatnya diskresi berada diantara hukum dan moral ${ }^{9}$.

Selanjutnya pekerja seks komersil prostitusi online yang telah ditetapkan sebagai korban, bukan berarti bahwa penanggulangan dan pemberantasan prostitusi online tidak tercapai namun dilakukan program penanggulangan dan pemberantasan terhadap prostitusi online melalui program-program kerja antara pemerintah daerah dan Kepolisian daerah Jambi sebagai berikut :

1. Pusat Pelayanan terpadu

Perlindungan hukum dalam bentuk perawatan medis, psikologis dan konseling termasuk penampungan dan pemulangan ke daerah asal korban, menjadi tanggung jawab sektor-sektor sesuai dengan tugas dan fungsinya. Kesepakatan Bersama Menteri Negara Pemberdayaan Perempuan, Menteri Kesehatan, Menteri Sosial dan Kepala Kepolisian Negara RI Nomor: 14/Men.PP/Dep.v/X/2002;1329/MENKES/ SKB/ X/ 12002;75/HUK/2002; POL.B/3048/X/ 2002 tentang Pelayanan Terpadu Korban Kekerasan Terhadap Perempuan dan Anak, diwujudkan dengan membentuk Pusat PelayananTerpadu di beberapa rumah sakit umum Pusat dan Daerah serta rumah sakit Kepolisian, agar korbandapat dengan mudah mengakses layanan yang diperlukan baik aspek medis, psikis, maupun aspek sosialdan hukum. Sebagai pelaksana Pusat Pelayanan Terpadu adalah dokter dan perawat terkait, psikolog, penyidik POLRI, serta dapat bekerjasama dengan pekerja sosial secara terpadu di bawah koordinasi pimpinan Pusat Pelayanan Terpadu yang bersangkutan.

2. Rumah Aman.

Eksistensi Rumah aman dapat memberikan perlindungan pada korban, seringkali rumah aman itu terbuka dan lokasi diketahui umum.Padahal

\footnotetext{
${ }^{9}$ AKP Yanepi, Penyidik Ditreskrimum Polda Jambi, Wawancara Tanggal 5 Agustus 2019
} 
tujuannya adalah menjadi tempat aman sementara bagi korban baik karena memerlukan tempat singgah sementara atau karena keamanannya terancam.

3. Pelayanan Perempuan dan Anak.

Polisi Wanita bagian Humas Polda Jambi memberikan layanan kepada perempuan pekerja seks komersil tentang pemahaman dan kesadaran hukum tentang perdagangan orang.

Sehingga menurut peneliti perlu dilakukan perlindungan terhadap korban prostitusi online sebagaimana menurut Harkristuti Harkrisnowo, ${ }^{10}$ yaitu :

a. perlindungan yang berkaitan dengan identitas diri. Perlindungan ini berkaitan dengan identitas diri korban, selama proses peradilan berjalan. Tujuan dari perlindungan ini adalah untuk mencegah terjadinya ancaman dari pihak pelaku yang mungkin terjadi selama berlangsungnya proses peradilan;

b. bantuan medis dan psikologis. Bantuan ini sangat diperlukan bagi korban yang mengalami penderitaan fisik serta mengalami gangguan psikologis. Korban dari kejahatan human trafficking sangat rawan dengan penderitaan fisik dan Psikologis. Bantuan dalam bentuk ini sangat penting untuk diberikan;

c. selain perlindungan sebagaimana tersebut di atas, korban perlu pula mendapatkan bantuan di bidang hukum. Bantuan hukum, sangat diperlukan dalam rangka menempuh proses hukum. Korban human trafficking lazimnya adalah orang-orang yang tidak memiliki pengetahuan yang memadai di bidang hukum. Oleh karena itu merupakan suatu keharusan untuk memberikan bantuan hukum, dalam rangka menggapai keadilan;

d. kompensasi dan restitusi. Korban berhak memperoleh kompensasi dan restitusi. Penderitaan korban, selain menjadi tanggung jawab si pelaku juga menjadi tanggung jawab negara.

Penanggulangan kejahatan akan dapat berhasil manakala komponen- komponen dalam sistem peradilan pidana yang terdiri dari kepolisian, kejaksaan, pengadilan dan lembaga pemasyarakatan bekerjasama secara terpadu. Keterpaduan dimaksud layaknya bejana berhubungan dengan pengertian setiap masalah dalam satu komponen akan menimbulkan dampak pada komponen lainnya. ${ }^{11}$

\footnotetext{
${ }^{10}$ Ibid, hal 113

${ }^{11}$ Mardjono Reksodiputro, Hak Asasi Manusia Dalam Sistem Peradilan Pidana, Pusat Pelayanan Keadilan dan Pengabdian Hukum, Jakarta, 1997, hal. 14
} 
Lebih lanjut ditegaskan oleh Mardjono Reksodiputro ${ }^{12}$ bahwa apabila keterpaduan dalam sistem bekerjasama tidak dilakukan, maka ada 3 (tiga) kerugian yang dapat diperkirakan timbul, yaitu :

a. Kesukaran dalam menilai sendiri keberhasilan atau kegagalan masing-masing instansi, sehubungan dengan tugas mereka bersama;

b. Kesulitan dalam memecahkan sendiri masalah-masalah pokok masing-masing instansi;

c. Karena tanggung jawab masing-masing instansi sering kurang jelas terbagi, maka dari sistem setiap instansi tidak perlu memperhatikan efektifitas menyeluruh peradilan pidana.

Tak dapat dipungkiri bahwa masalah prostitusi online merupakan perdagangan orang menimbulkan keprihatinan diberbagai kalangan. Masalah yang berskala nasional bahkan masuk lingkup internasional ini membuat berbagai pihak memberikan perhatian khusus, apalagi korbannya tidak sedikit jumlahnya. Pemerintah Indonesia yang berkewajiban memberikan perlindungan pada warganegaranya dinilai kurang serius menangani masalah ini. Meskipun dalam beberapa kasus seperti pemerintah Provinsi dan Pemerintah Daerah di Jambi membentuk tim khusus dan saling berkoordinasi kegiatan instansi vertical di daerah, namun yang sering terjadi adalah ketidakjelasan penyelesaian dari kasus yang ditangani. Pembentukan tim khusus dalam menangani masalah perdagangan manusia ini dilakukan karena disadari bahwa perdagangan manusia merupakan masalah yang kompleks yang menyangkut berbagai aspek.

Kerjasama yang dilakukan di Provinsi Jambi meliputi Pemerintah, Pemerintah Daerah, dan masyarakat dengan membentuk gugus tugas yang beranggotakan wakil-wakil dari pemerintah, penegak hokum, organisasi masyarakat, lembaga swadaya masyarakat, organisasi profesi, dan peneliti/akademisi. Gugus tugas ini memiliki tugas (Pasal 58 ayat (4)) yaitu :

1. Mengkoordinasikan upaya pencegahan dan penanganan tindak pidana perdagangan orang

2. Melaksanakan advokasi, sosialisasi, pelatihan dan kerjasama

3. Memantau perkembangan pelaksaksanaan perlindungan korban meliputi rehabilitasi, pemulangan dan reintegrasi social

4. Memantau perkembangan pelaksanaan penegakan hokum; serta

5. Melaksanakan pelaporan dan evakuasi

12 lbid, hal. 85 
Agar upaya pencegahan ini berjalan lancar maka adanya anggaran yang dikhususkan oleh Pemerintah Pusat maupun Pemerintah Daerah. Dan hal ini telah dilaksanakan oleh Pemerintah maka diterbitkanlah Peraturan Presiden Nomor 69 Tahun 2008 tentang Gugus Tugas Pencegahan dan Penanganan Tindak Pidana Orang yang memberikan laporan tahunan dan lima tahunan terdiri dari Gugus Tugas Pusat yang bertanggung jawab langsung kepada presiden, Gugus Tugas Provinsi berada dibawah dan Bertanggungjawab kepada Gubernur selanjutnya Gugus Tugas Kabupaten/Kota yang berada dibawah dan bertanggung jawab kepada Bupati/Walikota seperti halnya halnya Provinsi Jambi yang telah membentuk Gugus tugas Pencegahan dan Penanganan Tindak Pidana Perdagangan Orang di Provinsi Jambi berdasarkan Peraturan Gubernur Jambi Nomor 16 Tahun 2011 yang mempunyai tugas (Pasal 4) sebagai berikut :

a. Mengkoordinasikan pelaksanaan upaya penghapusan tindak pidana perdagangan orang sesuai dengan tugas dan fungsi masing-masing

b. Melaksanakan advokasi, sosialisasi, pelatihan dan kerjasama

c. Memantau perkembangan pelaksanaan perlindungan korban meliputi rehabilitasi, pemulangan dan reintegrasi soaial

d. Memantau perkembangan pelaksanaan penegakan hokum

e. Melaksanakan pelaporan dan evakuasi

\section{G. Kesimpulan}

Berdasarkan uraian pembahasan permasalahan di atas, maka dapat disimpulkan bahwa :

1. Pengaturan penetapan pelaku pekerja seks komersil prostitusi online sebagai korban tindak pidana perdagangan orang menurut hukum pidana Indonesia telah diatur di dalam Undang Undang RI No.19 Tahun 2016 Tentang Perubahan Undang Undang Nomor 14 Tahun 2008 tentang Informasi dan Transaksi Elektronik. Undang Undang RI No.19 Tahun 2016 merupakan perubahan Undang Undang Nomor 14 Tahun 2008 tentang Informasi dan Transaksi Elektronik dalam rangka untuk menjamin pengakuan serta penghormatan atas hak dan kebebasan orang lain dan untuk memenuhi tuntutan yang adil sesuai dengan pertimbangan keamanan dan ketertiban umum dalam suatu masyarakat yang demokratis

2. Dasar penetapan Kepolisian Daerah Jambi terhadap pelaku pekerja seks komersil prostitusi online sebagai korban tindak pidana perdagangan orang berdasarkan 
pertimbangan - pertimbangan yang dilakukan oleh Penyidik Kepolisian Daerah Jambi yang memiliki hak diskresi hubungan nilai-nilai yang dijabarkan di dalam kaidah-kaidah yang mantap dan mengejawantah dan sikap tindak sebagai rangkuman penjabaran nilai tahap akhir, untuk menciptakan, memelihara dan mempertahankan kedamaian pergaulan hidup.

3. Penanggulangan dan pemberantasan prostitusi online di wilayah hukum Kepolisian Daerah Jambi bila pelaku pekerja komersil prostitusi online hanya ditetapkan sebagai korban tetap dapat tercapai melalui Kerjasama yang dilakukan di Provinsi Jambi meliputi Pemerintah, Pemerintah Daerah, dan masyarakat dengan membentuk gugus tugas yang beranggotakan wakil-wakil dari pemerintah, penegak hokum, organisasi masyarakat, lembaga swadaya masyarakat, organisasi profesi, dan peneliti/akademisi sebagai berikut :

a. Mengoordinasikan upaya pencegahan dan penanganan tindak pidana perdagangan orang

b. Melaksanakan advokasi, sosialisasi, pelatihan dan kerjasama

c. Memantau perkembangan pelaksaksanaan perlindungan korban meliputi rehabilitasi, pemulangan dan reintegrasi social

d. Memantau perkembangan pelaksanaan penegakan hokum; serta

e. Melaksanakan pelaporan dan evakuasi

\section{H. Rekomendasi}

Bertitik tolak dari kesimpulan di atas, maka penulis menyampaikan rekomendasi sebagai berikut :

1. Untuk ditingkatkan kinerja tim gabungan Pemerintah Provinsi Jambi, Pemerintah Daerah Kabupaten dan Kota di Provinsi Jambi, Kepolisian Daerah Jambi dalam penanggulangan dan pemberantasan prostitusi online agar tidak marak terjadi di Provinsi Jambi

2. Untuk ditingkatkan kembali sosialisasi kepada masyarakat tentang pemutusan mata rantai beralihnya modus perdagangan orang dari konvensional ke pemanfaatan data jaringan internet dan razia - razia ke lokasi-lokasi penginapan-penginapan di Provinsi Jambi 


\section{DAFTAR PUSTAKA}

Ashadi Siregar, Menyusuri Remang-Remang Jakarta, Sinar Harapan, Jakarta, 1997

Arikunto,Suharsini, 2006, Manajemen Penelitian, Rineka Cipta, Jakarta.

B. Simanjuntak, Pengantar Patologi Sosial, Tarsito, Bandung, 2005

Barda Nawawi Arief, Masalah Penegakan Hukum dan Kebijakan Penanggulangan

Kejahatan, PT. Citra Aditya Bakti, Bandung, 2001.

Barda Nawawi Arief, Bunga Rampai Kebijakan Hukum Pidana, Citra Aditya Bakti, Bandung, 2002

Barda Nawawi Arief, Kapita Selekta Hukum Pidana, Citra Aditya Bakti, Bandung, 2003,

Dikdik M Arief Mansur dan Elisatris Gultom, Urgensi Perlindungan Korban Kejahatan (Antara Norma dan Realita), Jakarta : PT. Radja Grafindo Persada, 2006

Harkristuti Harkrisnowo, Reformasi Hukum: Menuju Upaya Sinergistik Untuk Mencapai Supermasi Hukum yang Berkeadilan, Jurnal Keadilan Vol. 3, No. 6 Tahun 2003/2004.

Haanen, C.,Wenegar, Pengantar Ilmu Penyakit Darah, Binacipta, Bandung, 2011

Handayani, Wiwik, dan Haribowo, Andi Sulistyo, Asuhan Keperawatanpada Klien dengan Gangguan Sistem Hematologi, Salemba Medika, Jakarta, 2008

Harkristuti Harkrisnowo, Indonesia Court Report: Human Trafficking, Universitas Indonesia Human Right Center, Jakarta, 2003

Heni Siswanto, Rekonstruksi Sistem Penegakan Hukum Pidana Menghadapi Kejahatan Perdagangan Orang, Pustaka Magister, Semarang, 2013

I Made Winaya, Hematologi Klinik Ringkas, EGC, Jakarta, 2006

J.J.H. Bruggink, 2009, Refleksi tentang Hukum, Citra Aditya Bhakti, Bandung.

Jimly Asshiddiqie, 2008, Agenda Pembangunan Hukum Nasioanal di Abad Globalisasi, Balai Pustaka, Jakarta.

Kartini Kartono, Pemimpin Dan Kepemimpinan, PT. Raja GrafindoPersada, Jakarta, 2003

Langit Kaha Wong Teleng, Melibas Sekat Pembatas, CV. Qalam, Yogyakarta, 2004

Moh. Rasyid, Pendidikan Seks, Syiar media publishing, Semarang, 2007

Mahrus Ali dan Bayu Aji Pramono, Perdagangan Orang: Dimensi, Instrumen Internasional dan Pengaturannya di Indonesia, Citra Aditya Bakti, Bandung, 2011

Mudjijono, Sarkem, Reproduksi Sosial Pelacur, Gadjah Mada University Press, Yogyakarta, 2005

Mardjono Reksodiputro, Kriminologi dan Sistem Peradilan Pidana, Kumpulan Karangan Buku Kedua, Pusat Pelayanan Keadulan dan Pengabdian Hukum (d/h Lembaga Kriminologi), Universitas Indonesia, Jakarta, 2007

Muladi, "Kapita Selekta Slstem Peradilan Pidana" Badan Penerbit UNDIP, Semarang, 1995

Rakhmat Jalaluddin,Psikologi Komunikasi, PT. RemajaRosdakarya, Bandung, 2010

Sudarto, Hukum dan Hukum Pidana, Alumni, Bandung.

S Simandjuntak, Patologi Sosial, Tarsito, Bandung, 2012 